\title{
PENINGKATAN HASIL BELAJAR PAI DENGAN METODE TEAM QIUZSISWA KELAS VI
}

\author{
Ernawati \\ Guru SDN 07 Pontianak Timur
}

\begin{abstract}
The purpose of the research is to improve students achievement using Team Quiz method on the sixth grade of 07elementary school in East Pontianak, Pontianak City (Borneo). This research was Classroom Action Research, using John Elliotl model. The subjects were sixth grade students. The data were collected through achievement test, observation sheets, questionnaires, and documentation. The data were analyzed using descriptive quantitative and qualitative analysis. The results show that the implementation of Team Quiz method can improve the process and the results of religion studies on the sixth grade. The improvement of learning process shown by students that are more active and communicative. In addition, the results indicated by the percentage of completeness in pre-action amounted to $41,93 \%, 61,29 \%$ in the first cycle, and $90,32 \%$ in the second cycle.
\end{abstract}

\section{Keyword:PAI,Team Qiuz}

\section{PENDAHULUAN}

Saat proses belajar mengajar berlangsung, idealnya seorang guru telah melakukan berbagai persiapan mengajar agar tujuan pembelajaran dapat tercapai sebagaimana mestinya. Diantara tujuan pembelajaran yang ingin dicapai adalah meningkatkan pemahaman siswa dan peningkatan hasil belajar siswa. Hal demikian erat kaitannya dengan kemampuan guru dalam mengembangkan program bimbingan dalam pengajaran Pendidikan Agama Islam (PAI) sebagai salah satu faktor yang berpengaruh terhadap siswa dalam belajar PAI.

Materi SKI sebenarnya tidak asing lagi bagi siswa yang berada di Madrasah Ibtidaiyah. Hal demikian berbeda bagi siswa Sekolah Dasar (SD) yang sifatnya umum dan cukup membuatnya belajar ekstra keras. Apalagi sesuai Peraturan Menteri
Pendidikan Nasional (Permendiknas) nomor: 22 tahun 2006 tentang standar isi untuk satuan pendidikan dasar dan Menengah pada lampiran 1 telah ditegaskan bahwa Standar Kompetensi Sejarah Kebudayaan Islam untuk siswa kelas VI semester genap dimana Kompetensi Dasar (KD) berisikan tentang perjuangan kaum Muhajirin dan kaum Ansar yang semestinya juga dapat dikuasai secara baik. Peneliti mengambil materi tentang perjuangan kaum Muhajirin dan kaum Ansar didasarkan tuntutan kurikulum Sekolah Dasar. Selain itu, kedua kaum ini memiliki keistimewaan di mata Nabi Muhammad SAW, sehingga Allah SWT menerangkan perilaku mereka dalam Qs Al-Hasyar (59) ayat 9, berikut:

Dan mereka penduduk Madinah kaum Ansyhar, yang sudah 
beriman lebih dahulu, sangat cinta kepada saudarasaudaranya kaum Muhajirin. Sedikitpun mereka tidak iri hati terhadap saudara-saudaranya itu dan atas apa yang sudah diterimanya dari barang sitaan, malahan mereka lebih mengutamakan saudarasaudaranya tadi daripada dirinya sendiri, sekalipun mereka sangat membutuhkannya. Orang-orang yang dapat melepaskan dirinya dan sifat kekikiran, mereka itu adalah kaum yang bakal menang.

Berkenaan tuntutan sebagaimana Permendiknas Nomor: 22 tahun 2006 dimaksud, dan implementasinya di lapangan menunjukkan bahwa hasil belajar PAI yang dicapai siswa kelas VI, khususnya materi Sejarah Kebudayaan Islam (SKI) di SDN 7 Pontianak Timur masih perlu diupayakan peningkatan prestasinya. Apalagi diketahui daya serap belajar siswa sebagaimana hasil ulangan KD pada 12 Februari 2016 menunjukkan bahwa pemahaman siswa berdasarkan penilaian diperoleh rata-rata kelas dari 28 siswa sekitar 58.57 dan masuk dalam kategori sangat kurang. Sebagai informasi tambahan, sebanyak 18 siswa (dari 28 siswa) menunjukkan hasil belajar yang belum berhasil mencapai Kriteria Ketuntasan Maksimal (KKM) PAI yaitu 75.

Adapun faktor-faktor yang kemungkinan besar menjadi penyebabnya adalah:

1. Guru kurang memiliki kemampuan dalam penguasaan materi pelajaran. Akibatnya dalam kegiatan belajar mengajar sejumlah materi yang disampaikan tidak berlangsung secara sistematis dan cenderung membingungkan siswa.

2. Guru cenderung text books. Akibatnya siswa cepat mengalami kelelahan karena merasa bosan dalam kondisi belajar yang demikian.

3. Guru belum memiliki kemampuan dalam menentukan strategi pembelajaran yang tepat. Akibatnya kegiatan belajar mengajar berlangsung secara monoton atau kurang variasi sehingga kurang dapat meningkatkan pemahaman siswa berkenaan materi yang disampaikan.

4. Metode ceramah yang diketahui sudah mulai ditinggalkan dalam proses pembelajaran aktif, ternyata masih menjadi pilihan utama guru. Akibatnya komunikasi cenderung bersifat satu arah dan membuat siswa pasif sehingga siswa lebih merasa sebagai subyek pembelajaran yang semestinya aktif terlibat dalam proses belajar mengajar.

Untuk mengatasi masalah tersebut, ada banyak strategi pembelajaran yang ditawarkan oleh insan yang peduli dan berkecimpung dalam dunia pendidikan. Satu diantara strategi tersebut adalah dengan menerapkan strategi team quiz dalam proses pembelajaran. Sehubungan dengan hal itu, maka dalam penelitian tindakan kelas ini, guru yang sekaligus berperan sebagai peneliti berupaya untuk meningkatkan pemahaman siswa terhadap materi pembelajaran dengan menerapkan strategi team quiz. Seperti yang diungkapkan oleh Zaini, Munte, dan Aryani (2002:57) bahwa melalui 
penggunaan strategi team quiz setiap siswa diberikan tanggungjawab besar dalam penguasaan materi pembelajaran yang dibangun secara berkelompok dalam suasana menyenangkan.

Sehubungan dengan hal tersebut, maka dalam penelitian ini, guru yang sekaligus berperan sebagai peneliti menerapkan strategi team quiz untuk meningkatkan pemahaman siswa terhadap materi Sejarah Kebudayaan Islam dan hasil belajar PAI di kelas VI yang berjumlah 28 siswa pada SD Negeri 07 Pontianak Timur.

Tujuan pembelajaran merupakan subsistem dari sistem instruksional dan diantara tujuannya adalah meningkatkan pemahaman dan hasil belajar siswa. Proses pencapaian tujuan dimaksud melalui penerapan strategi, materi, metode dan alat pembelajaran, kondisi dan prosedur pembelajaran, serta kapasitas siswa dan guru yang harus terorganisir secara sistemik. Fathurrohman dan Sutikno (2007:27-28) menegaskan bahwa tujuan utama kegiatan mengajar adalah membelajarkan siswa, maka teramat bijak apabila guru mampu mengenal, memahami dan menerima karakter peserta didik berkaitan dengan: (1) Tingkat kecerdasan dan bakat anak; (2) Prestasi awal; (3) Perkembangan jasmani dan kesehatan; (4) Cita-cita, sikap, minat, dan hobi; (5) Kebiasaan dan latar belakang sosial keluarga; dan (6) Sifat-sifat khusus dan persoalan pribadi anak.

Meningkatkan pemahaman siswa berkenaan pelaksanaan kegiatan belajar mengajar dan sifatnya berlangsung di dalam kelas adalah substansi dari kegiatan pendidikan di sekolah. Pelaksanaan pengajaran adalah interaksi guru dengan siswa dalam rangka menyampaikan bahan pelajaran kepada siswa untuk mencapai tujuan pengajaran (Suryosubroto, 1997: 36). Berdasarkan kedua pendapat tersebut, dapatlah dimaknai, bahwa pelaksanaan proses belajar mengajar merupakan proses terjadinya interaksi guru dengan siswa dalam rangka transfer bahan pengajaran demi tercapainya pemahaman siswa sebagai bagian dari tujuan pengajaran yang diharapkan.

Sedangkan Pendidikan Agama Islam berarti "usaha-usaha secara sistematis dan pragmatis dalam membantu anak didik agar mereka hidup sesuai dengan ajaran Islam". (Zuhairani, 1983 : 27). Ajaran islam tidak memisahkan antara iman dan amal shaleh. Oleh karena itu, pendidikan islam adalah sekaligus pendidikan iman dan pendidikan amal dan juga karena ajaran islam berisi tentang ajaran sikap dan tingkah laku pribadi masyarakat menuju kesejahteraan hidup perorangan dan bersama, maka pendidikan islam adalah pendidikan individu dan pendidikan masyarakat. Semula yang bertugas mendidik adalah para Nabi dan Rasul selanjutnya para ulama, dan cerdik pandailah sebagai penerus tugas, dan kewajiban mereka (Drajat, 1992 : 25-28).

Selain daripada itu, Pendidikan Agama Islam dapat didefenisikan sebagai upaya untuk mengaktualkan sifat-sifat kesempurnaan yang telah dianugerahkan oleh Allah Swt kepada manusia, upaya tersebut dilaksanakan tanpa pamrih apapun kecuali untuk semata-mata beribadah kepada Allah (Bawani, 1993 : $65)$.

Pendapat ahli lain adalah:

1. Al-Syaibany mengemukakan
bahwa pendidikan
Islam adalah proses mengubah 
tingkah laku individu peserta didik pada kehidupan pribadi, masyarakat dan alam sekitarnya. Proses tersebut dilakukan dengan cara pendidikan dan pengajaran sebagai sesuatu aktivitas asasi dan profesi di antara sekian banyak profesi asasi dalam masyarakat.

2. Muhammad fadhil al-Jamaly mendefenisikan pendidikan Islam sebagai upaya pengembangan, mendorong serta mengajak peserta didik hidup lebih dinamis dengan berdasarkan nilai-nilai yang tinggi dan kehidupan yang mulia. Dengan proses tersebut, diharapkan akan terbentuk pribadi peserta didik yang lebih sempurnah, baik yang berkaitan dengan potensi akal, perasaan maupun perbuatanya.

Pendidikan Islam adalah suatu sistem yang memungkinkan seseorang (peserta didik) agar dapat mengarahkan kehidupannya sesuai dengan ideologis atau gaya pandang umat Islam selama hidup di dunia.

Keberhasilan proses belajar mengajar yang diselenggarakan guru di dalam kelas erat hubungannya dengan keterlibatan dua komponen yang saling bersistem, yaitu guru dan siswa. Selama proses belajar mengajar berlangsung, guru dituntut memiliki kemampan untuk dapat menentukan strategi yang dianggap paling efektif dan efisien dalam rangka meningkatkan pemahaman dan hasil belajar siswa sebagaimana tujuan pembelajaran yang telah dicanangkan sebelumnya.

Banyak alternatif strategi yang ditawarkan untuk dapat disesuaikan secara tepat berkenaan materi dan kondisi belajar siswa, yang diantaranya adalah materi kisah perjuangan kaum Muhajirin dan kaum Ansar, dan dianggap lebih tepat manakala menggunakan strategi team quiz. Strategi team quiz menurut Zaini, Munte dan Aryani (2002:57-58), adalah suatu strategi pembelajaran yang dapat meningkatkan tanggung jawab belajar siswa/mahasiswa dalam suasana yang menyenangkan.

Satu hal yang perlu ditegaskan dari pendapat DePorter, Reardon SingerNourie dimaksud, bahwa kegiatan belajar yang diselenggarakan oleh guru harus memberi makna bagi siswa. Siswa merasa bahwa kegiatan belajar mengajar yang berlangsung, penuh dengan nuansa kegembiraan, dan faktor kelelahan yang biasanya melanda kondisi siswa maupun guru dapat dikurangi. Pengajaran yang diisi dengan kegembiraan dapat membantu menjaga pemutusan perhatian (Tafsir, 2001:26). Pengungkapan tersebut merupakan unsur penunjang berkenaan penggunaan strategi team quiz dalam rangka meningkatkan pemahaman dan prestasi belajar siswa.

Sementara itu, hasil penelitian yang dilakukan oleh Urai Dewi Erlianti (http://digilib.uin-

suka.ac.id/5205/)menunjukkan bahwa strategi pembelajaran aktif tipe team quizdapat meningkatkan kemampuan bertanya dan hasil belajar peserta didik pada pokok bahasan kelarutan dan hasil kali kelarutan kelas XI IPA 4 SMA Muhammdiyah 2 Yogyakarta tahun ajaran 2009/2010. Peningkatan kemampuan bertanya ditunjukkan oleh kenaikan rerata kemampuan bertanya peserta didik dari 11,43\% (pada siklus I) menjadi $25,71 \%$ (pada siklus II). Peningkatan hasil belajar kognitif peserta didik ditunjukkan dengan adanya nilai effect size antara siklus I dan siklus II sebesar 3,82. 
Selain itu, hasil penelitian tindakan kelas yang dilakukan oleh Adelaide Yunitha mengungkapkan bahwa pada siklus I, siswa yang mencapai KKM, hanya 10 siswa dari 30 siswa atau sekitar 35\%. Pada siklus II, siswa yang mencapai KKM yaitu 23 siswa dari 30 siswa atau sekitar $85 \%$. Sehingga disimpulkan bahwa terjadi peningkatan hasil belajar siswa setelah diterapkan pembelajaran IPS dikelas IV SD model kooperatif tipe Team Quiz.

Penggunaan model pembelajaran aktif tipe Team Quiz diharapkan dapat memudahkan siswa mengingat dan memahami keseluruhan informasi yang disampaikan oleh guru.

\section{METODE}

Penelitian ini termasuk dalam penelitian tindakan kelas (classroom action research). Tujuan penelitian ini adalah untuk meningkatkan proses dan hasil belajar PAI menggunakan model pembelajaran aktif tipe Team Quiz pada kelas VI di SD Negeri 07 Pontianak Timur, kota Pontianak (Kalbar). Penelitian tindakan kelas ini dilaksanakan kelas VI di SD Negeri 07 Pontianak Timur, kota Pontianak (Kalbar) selama bulan September 2017.

Subjek penelitian ini adalah guru dan siswa kelas VI SD Negeri 07 Pontianak Timur, kota Pontianak (Kalbar) tahun ajaran 2017/2018. Jumlah siswa ada 31 terdiri dari 14 siswa perempuan dan 17 siswa laki-laki. Alasan pemilihan subjek ini karena hasil belajar PAI siswa kelas VI masih rendah, sementara itu guru masih melaksankan pembelajaran secara konvensional.
Penelitian ini menggunakan model John Elliot yang tampak lebih detail dan rinci.

Nilai hasil belajar siswa dapat dihitung menggunakan rumus sebagai berikut:

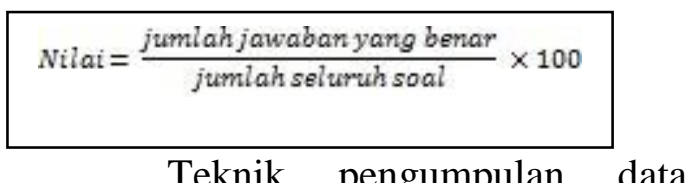

dalam penelitian ini dengan menggunakan metode observasi dan dokumentasi. Observasi dilakukan untuk mengamati aktivitas guru dan siswa, angket untuk mengetahui ketertarikan guru dan siswa terhadap proses pembelajaran, dan dokumentasi selama proses pembelajaran. Tes dalam penelitian ini menggunakan tes hasil belajar yang berupa soal pilihan ganda sebanyak 10 soal. (1) Lembar Observasi/ Pengamatan, (2) Lembar Angket (3) Soal Tes.

Analisis data dalam penelitian ini mengacu pada instrumen penelitian yang digunakan, instrumen yang dimaksud yaitu lembar observasi/ pengamatan, lembar angket, dan soal tes hasil belajar. Teknik analisis data dalam penelitian ini menggunakan teknik analisis data kuantitatif dan kualitatif. Teknik analisis kuantitatif untuk menganalisis hasil tes tindakan dengan menggunakan teknik analisis data secara statistik deskriptif. Sedangkan teknik analisis kualitatif untuk menganalisis hasil observasi/ pengamatan. Analisis data kuantitatif ini berupa nilai hasil tes, nilai rerata, serta menggunakan rumus sebagai berikut: 


$$
X=\sum_{N}^{\sum X}
$$

Keterangan:

$X \quad$ : rata-rata (mean)

$\sum_{\mathrm{N}} \quad X \quad$ : jumlah seluruh skor : banyaknya subjek

Sedangkan rumus untuk menghitung persentase keberhasilan pembelajaran adalah sebagai berikut:

$$
P=\frac{f}{N} \times 100 \%
$$

Keterangan:

$\mathrm{P}$ : Angka persentase

f : Frekuensi yang sedang dicari persentasenya

$\mathrm{N}$ : Number of Cases (jumlah frekuensi/ banyaknya individu)

\section{HASIL DAN PEMBAHASAN \\ Hasil}

Dalam pembahasan ini diuraikan mengenai hasil dari penelitian yang telah dilaksanakan. Keberhasilan terhadap hasil belajar dan proses pembelajaran yang dicapai dalam pembelajaran PAI melalui model pembelajaran aktif tipe team quizsebagai berikut:

Tabel 1. Perbandingan Hasil Belajar Pra

Tindakan, Siklus I, dan Siklus II

\begin{tabular}{llcc}
\hline Kriteria & $\begin{array}{l}\text { Pra } \\
\text { Tindakan }\end{array}$ & Siklus I & Siklus II \\
& &
\end{tabular}

\begin{tabular}{lllllll}
\hline Tuntas & 13 & $\begin{array}{l}41, \\
93\end{array}$ & 19 & $\begin{array}{l}61,29 \\
\%\end{array}$ & 28 & $\begin{array}{l}90,32 \\
\%\end{array}$ \\
& & & & & \\
& & & & & \\
\hline Belum & 18 & 58, & 12 & 38,70 & 3 & 9, \\
Tuntas & & 06 & & $\%$ & & 67 \\
& & $\%$ & & & & $\%$ \\
\hline Rata- & & & & & \\
\hline \multicolumn{7}{l}{} \\
rata & 60,47 & 73.85 & 87,70 & \\
\hline
\end{tabular}

Dari tabel di atas dapat dilihat bahwa nilai hasil belajar siswa meningkat dari pra tindakan ke siklus I dan siklus II. Siswa yang tuntas pada pra tindakan sebanyak 13 siswa atau sebesar 41,93\% menjadi 19 siswa atau sebesar 61,29\% pada siklus I dan mencapai 13 siswa atau sebesar 90, 32\% pada siklus II. Siswa yang belum tuntas pada pra tindakan sebanyak 18 siswa atau sebesar 58,06\% menjadi 12 siswa atau sebesar $38,70 \%$ pada siklus I dan mencapai 3 siswa atau sebesar 9,67\% pada siklus II. Sedangkan nilai rata-rata pada pra tindakan sebesar 60,47 menjadi 73,85 pada siklus I dan mencapai 87,70 pada siklus II. Nilai tertinggi juga meningkat dari 80 pada pra tindakan menjadi 90 pada siklus I dan menjadi 100 pada siklus II.

Berdasarkan hasil penelitian dari hasil tes dan pengamatan yang telah dikemukakan di atas, pada pelaksanaan tindakan siklus I dan Siklus II dapat meningkatkan prestasi belajar siswa dengan diterapkannya strategi pembelajaran metode konvensional dan strategi team quiz.

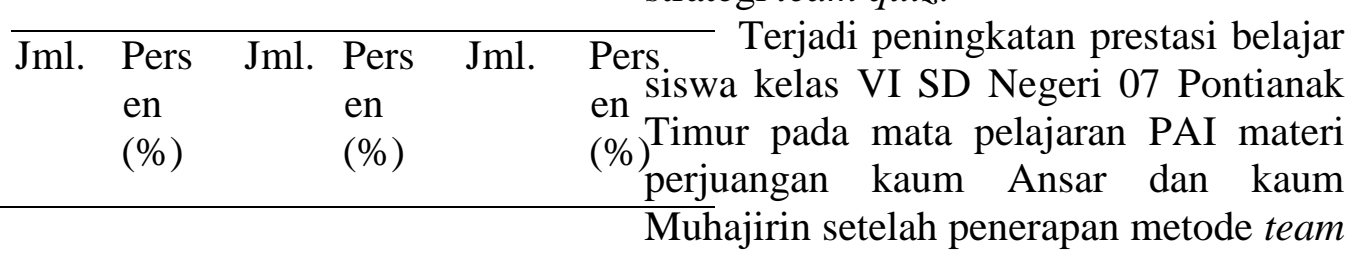


quiz dimana pada siklus I pertemuan pertama ada 14 siswa atau $45 \%$ yang memperoleh nilai baik dan baik sekali. Pada pertemuan kedua ada 20 siswa atau $64,5 \%$ yang mendapat nilai baik dan baik sekali. Selanjutnya pada siklus II pertemuan pertama ada 21 siswa atau $67,7 \%$ yang mendapat nilai baik dan baik sekali. Pada pertemuan kedua ada 26 siswa atau $83,8 \%$ yang berhasil mendapat nilai baik dan baik sekali. Inimenunjukkan bahwa pembelajaran yang dilakukan berhasil dan sesuai dengan indikator yang telah ditetapkan yaitu rata-rata nilai hasil kuis 70 sebanyak $75 \%$ dari jumlah peserta didik telah terpenuhi.

Sehingga dapat disimpulkan bahwa proses pembelajaran pada pra siklus dengan menggunakan metode konvensional interaksi pembelajaran hanya terjadi pada satu arah yaitu guru yang aktif dan siswa yang pasif sehingga menjadikan siswa tidak berusaha memahami materi yang diajarkan, karena tidak diberikan kesempatan untuk mengkaji materi, sedangkan pada siklus I dengan menggunakan metode team quiz siswa sudah diberi banyak kesempatan untuk mengkaji materi dengan diskusi kelompok kecil, motivasi belajar juga semakin meningkat karena siswa tidak hanya dan duduk dan mendengar penjelasan dari guru sehingga mengantuk, tetapi mereka bisa belajar dan berdiskusi dengan temannya. Namun keaktifan belajar siswa pada siklus I ini masih belum merata terjadi pada peserta didik, masih ada beberapa siswa yang kurang antusias, ini disebabkan karena kurangnya guru dalam mensetting kelas yang komunikatif, kurangnya guru dalam mengelilingi kelompok kerja siswa, guru kurang dapat menggunakan media pembelajaran sebagai alat bantu pendidikan.

Kekurangan pada siklus I menjadi rujukan bagi guru untuk memperbaiki pembelajaran pada siklus II dengan melakukan proses pembelajaran menggunakan metode team quiz dengan mesetting kelas dengan formasi huruf $\mathrm{U}$, guru menerangkan materi secara detail, memvariasi pembelajaran dengan menggunakan media gambar dan membagi siswa dalam kelompok yang lebih kecil lagi agar siswa lebih aktif. Guru melakukan pendekatan kepada siswa untuk memberikan motivasi ketika melakukan diskusi dalam kerja team quiz sehingga proses diskusi dalam kelompok dapat berjalan dengan baik.

Perbaikan-perbaikan yang dilakukan guru menjadikan pembelajaran PAI materi perjuangan kaum Ansar dan kaum Muhajirin di kelas VI SD Negeri 07 Pontianak Timur dengan menerapkan metode team quiz telah menjadikan siswa termotivasi dalam pembelajaran. Indikasinya siswa sudah antusias mendengarkan penjelasan guru, siswa telah antusias membuat pertanyaan dan jawaban, siswa telah antusias dalam kerja kelompok dan siswa telah antusias dalam mengomentari hasil kerja teman. Metode team quiz ini juga menjadikan mereka mudah memahami materi yang diberikan sehingga hasil tes dengan KKM 75 telah mencapai diatas $80 \%$ sebagaimana target yang diharapkan.

Sehingga setelah pelaksanaan siklus II ini maka tidak perlu ada siklus selanjutnya. Hipotesis yang diajukan peneliti yang berbunyi "Penerapan strategi pembelajaran aktif model team quizdapat meningkatkan Hasil Belajar PAI Siswa Kelas VI di SD Negeri 07 
Pontianak Timur" dalam penelitian ini telah terjawab atau terbukti.

\section{SIMPULAN DAN SARAN Simpulan}

Berdasarkan hasil penelitian dan pembahasan pada bab IV maka dapat disimpulkan bahwa strategi pembelajaran aktif model team quizdapat meningkatkan kualitas pembelajaran dan hasil belajar PAI siswa kelas VI di SD Negeri 07 Pontianak Timur, kota Pontianak (Kalbar). Penggunaan strategi pembelajaran aktif model team quiztersebut dilakukan dengan baik sehingga berdampak pada meningkatnya hasil belajar siswa.

Tes hasil belajar pada pada siklus I diperoleh nilai rata-rata kelas sebesar 73,85 dengan ketuntasan belajar sebesar $61,29 \%$. Pada siklus II diperoleh nilai rata-rata kelas sebesar 87,70 dengan ketuntasan belajar $90,32 \%$. Secara proses, hasil belajar dapat dilihat dari meningkatnya kualitas pembelajaran, yaitu siswa menjadi aktif, lebih antusias, dan pembelajaran menjadi lebih menyenangkan bagi siswa. Hal tersebut sesuai dengan hasil pengamatan terhadap aktivitas siswa dan guru dalam menerapkan strategi pembelajaran aktif model team quiz.

Hal-hal yang perlu diperhatikan guru dalam menerapkan strategi pembelajaran aktif model team quizpada pembelajaran PAI adalah sebagai berikut (1) guru harus melaksanakan pembelajaran PAI dengan efektif dan efisien dengan menerapkan langkah- langkah strategi pembelajaran aktif model team quiz dengan tepat; (2) suasana kelas dan pembelajaran harus dibuat santai tetapi serius dan menyenangkan sehingga siswa merasa percaya diri dan komunikatif dengan guru.

\section{Saran}

Pembelajaran yang dilakukan oleh guru sebaiknya menerapkan metodemetode belajar yang menarik dan menyenangkan sehingga siswa lebih antusias dalam mengikuti pembelajaran. Salah satu metode pembelajaran yang disarankan oleh peneliti dan dapat diterapkan oleh guru adalah strategi pembelajaran aktif model team quiz. Hasil yang dicapai siswa dalam penelitian ini diupayakan untuk tetap dipertahankan. Selain itu, penelitian ini diharapkan dapat menjadi tambahan pengetahuan bagi para peneliti berikutnya dalam menerapkan strategi pembelajaran aktif model team quiz pada mata pelajaran PAI.

\section{DAFTAR RUJUKAN}

Andayani. 2009. Pemantapan Kemampuan Profesi. Universitas Terbuka. Jakarta

Andri Saleh. (2009). Kreatif Mengajar denganTeam Quiz.

Bogor: CV. Regina.

Arikunto, Suharsimi. 2011.

Penelitian Tindakan Kelas.

Bumi Aksara. Jakarta.

Arifin, Zainal. 2011. Evaluasi

Pembelajaran. Remaja

Rosdakarya. Bandung.

Aqib, Zainal, dkk. 2010. Penelitian Tindakan Kelas (PTK) untuk Guru SD, SLB, TK. Yrama Widya. Bandung.

Departemen Pendidikan Nasional. (2008).

Peraturan Menteri Pendidikan Nasional. Departemen Pendidikan Nasional Direktorat Jenderal. 
Jakarta: Manajemen Pendidikan Dasar dan Menengah.

Depdiknas. (2004a). Pedoman

Pengembangan Instrumen dan Penilaian Ranah Afektif. Jakarta: Ditjen Dikdasmen.

Ismail SM, Strategi Pembelajaran Agama Islam Berbasis PAIKEM. Bumi Aksara. Jakarta.
Nana Sudjana. (2005). Penilaian Hasil Proses Belajar Mengajar. Bandung: PT Remaja Rosdakarya.

Suharsimi Arikunto. (2013). Prosedur Penelitian Suatu Pendeketan Praktik. Jakarta: PT Rineka Cipta. 

